\title{
Evolution of Motives in Professional Personality Formation: Foreign Language Learning Context
}

\author{
Irena $\mathrm{V}$. Aleshchanova \\ dept. Foreign Languages \\ and Humanities \\ Kamyshin Technological Institute \\ branch of VSTU \\ Kamyshin, Russia \\ irenavale@yandex.ru
}

\author{
Natalia A. Frolova \\ dept. Foreign Languages \\ and Humanities \\ Kamyshin Technological Institute \\ branch of VSTU \\ Kamyshin, Russia \\ fnataliefnatalie@gmail.com
}

\author{
Marina R. Zheltukhina \\ dept. Theory of English \\ Volgograd State \\ Socio-Pedagogical \\ University \\ Volgograd, Russia \\ zzmr@mail.ru
}

\begin{abstract}
The research focuses on motivational issues of educational process in modern socio-cultural environment. The aim of the paper is to investigate the rate of a professional component influence on the dynamics of motivational modifications and transformations in the process of professional personality formation. Experimental findings on the issues of modification of motives to grow professionally among technical university students, who learn professional aspects of foreign languages, are presented. In this paper the authors show how to create positive motivation to acquire the ability to use a foreign language in professional communication among engineering students. The ideas are supported with methodological instructions.
\end{abstract}

Keywords - education, university education, foreign language learning, professional personality formation, motivation, motive, transformation of motives.

\section{INTRODUCTION}

Complexity of social interaction determines the growing role of education in today's changing social world. The importance of studying the problems of education is caused by close interaction between education and various aspects of public life (economy, politics and culture). Education forms understanding of everything that exists everywhere, and helps create a value-system among young people while they investigate different social processes and phenomena including sub components. Ultimately, it provides opportunity for the further development of the whole community.

Social activity of a person is regulated by definite goals. Together they form a motivational sphere. Professional education, being one of the dominant goals, occupies its special position in the hierarchy of needs. Consequently, stimulating and motivational components in education are leading ones, and actualize necessity to find new and more effective ways to keep young people motivated so to grow professionally and perform well.

Education as a process takes place in a specific social and cultural environment, and shows stable dependence on processes which occur in it. Educational social and cultural environment is a structural element of general social and cultural environment. Its conditions are influenced by external and internal factors. External factors include contextual conditions of education (social and economic situation, local social and cultural environment, profile of the educational organization and specific character of the educational process). Internal factors of educational and socio-cultural environment are learners' personal and situational characteristics, their innate way of life and inner world, worldview and self-awareness, needs, life goals, values, motives influencing the direction of education. The set of the above factors forms the motivational structure of educational activity.

Motivation is a complex social and cultural phenomenon, which determines the nature of individual behavioral manifestations and, accordingly, the direction of activity. The most important element in the content of motivation is a motive. Motives as functional units make up the motivation of behavior. The system of motives has complex contents, gives active and dynamic character to education, forms a part of its structure and defines its semantic features. When studying motivation, it is therefore appropriate to view it as a complex system consisting of such important elements as motives, needs, interests, incentives and value orientation. Motivation to study is defined as a particular type of motivation included in social activity. This type of motivation allows a developing personality to find not only the direction, but also ways to implement various forms of education, engage emotional and volitional spheres.

\section{Methodology}

The research focuses on motivational basis of education. It consists of different interrelated social and individual motives considered in their dynamic development. Principles of conscious and motivated linguistic material learning, which form the basis for modern-day education is directed at intensification and improvement of the quality of learning a foreign language [1]. The transformation of students' intrinsic and extrinsic motivation is revealed in the context of professionally oriented foreign language learning.

The aim of the study is to conduct analysis of motivational changes during the period of learning a foreign language for professional communication.

The research material included Foreign Language syllabi, educational papers for professionally oriented foreign language learning, as well as the process of instruction in 
foreign language classes. Methods of classroom observation, students' questionnaires, specialists' interviews, learning outcomes based on testing, quantitative analysis and data processing were used as data collection tools in various aspects of the study.

It is necessary to overcome insufficient motivation in the system of modern university education to train specialists with foreign language skills. This can be done by transforming educational motives or developing productive motivational teaching methods in order to transfer the acquired knowledge to the category of sustainable skills [2]. In other words, the basic condition for a future specialist's development is a functional change in the motivational basis of education from the perspective of the activity and personality-oriented approaches to learning a foreign language. The gradual transition from the development of cognitive motives, which underlie the theoretical education to the formation of social, professional motives satisfying practical activities, supports the dynamic nature of learning.

Research studies on motivation describe and discuss various and numerous theoretical and practice-oriented issues in the field of education in general and foreign language learning in particular.

According to historical overview of different motivational theories in foreign language teaching by M. Guerrero, there are three basic stages an investigator follows to study motivation. These periods are named as social psychological phases, namely, a cognitive-situated phase and a processoriented one. Besides, a recent period in research studies on motivation can be described as socio-dynamic stage [3]. An important role is given to the activity, personality-oriented and contextual approaches in this modern phase.

Motivation is an ambiguous and multidimensional concept. It often goes beyond ordinary interpretation. That is why "motivation" can be considered as an "undifferentiated" or "over-differentiated" concept [4].

Pedagogical psychology explains educational motives as behavioral ones, providing people with new knowledge and skills based on existing ones [5].

From a cognitive perspective, a motive to study is understood as a desire, including an intention to acquire certain content or skills [6].

A sociological approach has its focus on socially distributed nature of motivation. Motivation is regarded as a complex construct that does not have a simple definition. It results from social processes in today's world that tend to impact both language education and language learners [7].

Thus, motivation appears as a collective term for emotional and cognitive processes that ensure students' intentional learning of something new to achieve expected results $[8,9]$. Consequently, students' personal expectations are an integral part of a motive to study.

Practice-oriented studies into motivation are devoted to investigation of the role of some didactic methods as reading [10], writing [11], role plays [12], flipped classroom method [13], etc. in raising the level of academic motivation.
In this study, motivation is defined as a complex emotional and volitional individual formation based on cause and effect relationship, consisting of a group of motives that generates and coordinates a certain type of activity. In turn, a motive is understood after A.A. Leont'ev [14] as a causal condition of an action, which determines its substantive and content characteristic features with a view to achieving the objectivel, that is, an actual need.

\section{RESULTS AND DISCUSSION}

In this connection, motivational basis of education should be explored, taking into account a combination of various scientific approaches applied to understand human motivation, individuality and psychological well-being of a student. Therefore, the problem of students' intrinsic and extrinsic motivation should be investigated in the context of professionally oriented education, i.e. studying a foreign language for professional communication.

Professional activity is an essential and the longest stage of a person's socialization. It is obvious that a specialist's personality development is possible if there is positive motivation to professional activity. Professional development implies both specialized skills improvement and individual self-improvement. Comparison of the positions of a student, a young professional and an expert shows the change in a social position of a person included in a professional field. A performer becomes a creator, simple application of knowledge and skills is replaced by the ability to analyze and critically assess the situation, and the simulative manner of professional activity acquires a creative nature. Professional development intensively changes the way people see their roles in professional activity. This change is a consequence of restructuring an individual motivational sphere as a result of direct participation in educational and professional activities and social environment influence.

Contents and conditions of professional activity are a combination of standardized and new, problematic situations. Therefore, the basis of professionally oriented instruction methods in language learning is the use of language units and structures to solve simulated problem situations involving students' active inclusion in a classroom activity. Planned outcomes of such organized training presuppose a possibility of applying professional information in practice on the basis of acquired linguistic and cultural knowledge and skills.

One of the main issues is the problem of balance between organizational norms in foreign languages study and forms of professional activity learnt by students. According to pedagogical methods of teaching a professional foreign language, two basic forms of activity can be distinguished: educational (practical training) and educational and professional (role-playing, organized independent work, students' educational and research work).

Communication and learning of linguistic and cultural information is carried out in the forms of educational activity. Educational and professional activities allow simulating the subject, social and role contents of the situations in the workplace, specialized professional actions and relations in foreign language classes [15]. 
Requirements for quality of modern education call for the need of considerable changes in methodology and content of a foreign language learning. Taken together various methods of learning realize a common goal of practical command of foreign languages in professional communication. Students are to learn general and specific rules of professional vocabulary, business and professional communication, oral and written translation, expand their professional experience and find opportunities to exchange it with foreign colleagues.

The process of students' positive motivation development can be effective if it is implemented as a consistent development of skills to work with linguistic materials. A complexity factor is increased gradually in this process while moving from the basic language level, presupposing knowledge of the basic language structures to the professional component of a foreign language.

Basic linguistic level acquisition consists in doing various lexical, grammar and communicative exercises to practice and consolidate basic aspects of the language, and learning general rules of business and professional communication. At this stage, tasks given to students help reveal a degree of their preparation for the subject and assess its level, learn to think independently, analyze language phenomena, and develop observation and contextual guess. At the next, more complicated stage, all tasks are developed to activate theoretical and practical knowledge, gain the ability to intercultural communication, formed on the basis of a professional and business component of foreign language teaching.

Actions of students in the implementation of these forms of their studies are to work efficiently with information in new educational situations that may closely simulate the conditions of social and professional activity (role games, preparation of presentations, creative assignments, research projects, business correspondence forms and etc.). Let us consider some kinds of modeling educational situations used to develop motivation while studying a professional aspect. Role-playing games make it possible to create demonstrative and practical or illustrative and modeling educational situations. In the first case, students are familiarized with the effectiveness of using verbal and non-verbal communication techniques from an example in the practical professional activity. In the second case, students are asked to solve some communicative problem, which can serve as a means of conveying verbal experience. The implementation of research projects and preparation of presentations immerses students in a situation of informational search, which requires preliminary study of special information sources, conducting research work, preparing problematic issues, developing an action plan and solutions, and forecasting a result. Preparation and presentation of creative assignments is defined in the work as appraisal and analytical situations. They presuppose critical evaluation of a communicative situation (for example, the actions of employees of a particular company), search for a way to solve it by means of analysis of existing verbal and non-verbal mechanisms, the most typical speech mistakes and the results received [16].
Transformation of motives during studies is influenced by numerous factors. There can be found two large groups of extrinsic and intrinsic motivating factors among them. Thus, motivation is a combination of extrinsic and intrinsic factors that make a person to be active. In this, extrinsic motivators include means of external influence, for example, interaction of participants in the educational process (instructors and fellow students), personality of the instructor, the organization of education, the degree of theme content complexity and other situational factors. Intrinsic motivation is determined by personal qualities of learning process participants. As a result, motivation in learning is formed through the influence of the entire system of pedagogical effects, but first it develops in the process of the direct educational activity. Students' intention to acquire professional skills forms prerequisites for the development of new motives. However, such increase in a motivational structure of education is possible only if students react positively to motivation for learning activity [16]. Therefore, it should be noted that the dynamics of motives in learning must be under constant supervision in order to prevent possible replacement of positive motives with negative ones under the influence of a number of situational factors.

From the social psychology perspective a period of study at university is characterized by formation of a person who acquires increasing economic, social and psychological independence, well-balanced combination of intellectual and social maturity. The study of such a particular social group as students allowed to reveal several specific features on the basis of its functional direction: 1. high focus on professional skills development based on scientifically organized university education; 2. content of the basic activity is represented by an educational process as the main form of general and special knowledge and skills accumulation in a certain scientific field to master a particular profession; 3. contextual conditions of students' basic activity are related to the specific conditions of their life and work. Taken as an object of study, this social group provides extensive illustrative material on the stages of motivational dynamics of future specialists' professional activities.

Study of mechanisms of students' intrinsic motivation development made it possible to identify three basic needs that ensure its natural functioning and contribute to the psychological well-being of the individual $[9,14]$ : 1) the need for autonomy; 2) the need for competence; 3) the need for interconnection with other people.

The need for autonomy described as an individual independent choice and performance appears to be the most important characteristic in supporting intrinsic motivation of each student. The need for competence has also an important role, though it is insufficient for keeping intrinsic motivation at a high level. The need for active social relationships is a prerequisite for a successful development and functioning of the need for autonomy. It was demonstrated in our experimental testing of such socially significant educational projects as "Training firm", "PRP" (Practice and Research Project), that provide students with feeling of unity with their classmates, a highly developed and highly effective level of autonomy [15]. 
As routine observations proved, numerous external environment events can have different effects on students' intrinsic motivation. However, the level of intrinsic motivation for the realized type of activity can increase if students perceive it because of their own will. In the case when students feel external control of their actions, the need for autonomy is oppressed, which in turn affects intrinsic motivation for learning a foreign language negatively. In this respect pedagogical tactics to activate learning by giving higher scores for regular attendance can be mentioned as an example. This technique is often perceived by students as a manipulative attempt to make them attend all practical classes.

The more external factors influence individual critical assessment of competence, the stronger intrinsic motivation becomes. Conversely, if a feeling of poor coping with a certain aspect of learning appears with a student, it weakens intrinsic motivation in this situation. For example, positive feedback and successfully performed task on the optimal level of difficulty will increase sense of competence in this field, and hence intrinsic motivation for further learning a foreign language. Negative feedback or inadequate level of the task difficulty does not meet need for competence, which will reduce intrinsic motivation level.

Thus, it has become possible to find existence of a relationship between a dominant category of values and psychological well-being of students.

Description of the process of motivational basis formation in foreign language classes according to the motives classification developed by T.A. Il'ina, in our opinion, can be considered illustrative enough [17]. Prompting motives (the interested creative personality of the instructor, pleasant training atmosphere created in the class, practical value of the lesson, innovative teaching methods directly actualize perspective prompting motives (interest in the subject, students' purposefulness and enthusiasm, positive attitude toward fulfilling the instructor's requirements, desire to gain a teacher and friends' approval). The task of the teacher in this process is to rationally organize a training structure, develop students' desire for success, support enthusiasm and keenness on the subject, express approval for the work done, avoid stressing failures and incorrect goal setting, remarks, pressure, demotivating training. As a rule, stable interests in learning arise in classes and depend on the evaluation of activities effectiveness [18-22]. It is creation of an atmosphere of comprehensive interest in a subject; its contents and significance that help achieve goals and objectives of education.

The role of a professional component in the development of a sustainable motive to learn a foreign language was investigated in the experimental part of the research. It was conducted in the Kamyshin Technological Institute (Russia) in a form of questionnaires and interviews in order to find out the factors that influence the activation of interest in language education. Research findings show different types of motives in education. The respondents' behavior during the interviews was influenced by the level of their education and their attitude to the interview situation, caused by their intrinsic motivation. Preliminary instructional advice on the aims and contents of the interview was a prerequisite for understanding and accomplishing the task.

Ninety respondents of different age and educational level took part in the study (see tables 1-3 below). Three experimental age groups took part in the experiment. The first group included the first year students studying technical subjects. Their core curriculum subjects included a basic course of a foreign language, respectively. Participants of the second group were second-year students studying the professional aspect of a foreign language. The third group included supplementary education programs students (undergraduate students, post-graduate students, production workers and employees) of the Linguistic Center at the Institute. According to the results of the study, the highest level of motivation was found in the third group compared with the second and first groups, and in the second group compared with the first one. This means that participation in professional activities, as well as transition to a professional level of education increase motivation. Specific character of professional activity motivation is closely connected with the age of students, and transition to the context of professional activity raises it. According to the theory of A. Maslow [18, 23-29], this age-related change in motives is caused by the influence of changing needs, which are in close interdependence with motives.

Tables 1-3, compiled on the basis of research findings, show classification of motives on the criteria of their contents and focus.

TABLE I. THE FIRST YEAR STUDENTS' MOTIVES IN PROFESSIONALLY ORIENTED FOREIGN LANGUAGE LEARNING

\begin{tabular}{|c|c|}
\hline Motives & Motivational Contents \\
\hline cognitive & interest in educational process and its result \\
\hline social & $\begin{array}{l}\text { performance of teacher's requests; desire to increase } \\
\text { rating scores; desire to fulfil duties; feeling of } \\
\text { personal responsibility }\end{array}$ \\
\hline axiological & prestige increase; aspiration for adulthood \\
\hline communication & $\begin{array}{l}\text { desire to establish contact; communication in a } \\
\text { foreign language in everyday situations }\end{array}$ \\
\hline
\end{tabular}

TABLE II. THE SECOND YEAR STUDENTS' MOTIVES IN PROFESSIONALLY ORIENTED FOREIGN LANGUAGE LEARNING

\begin{tabular}{|c|l|}
\hline Motives & \multicolumn{1}{|c|}{ Motivational Contents } \\
\hline cognitive & $\begin{array}{l}\text { interest in the process of problems solving and search } \\
\text { for the ways of their solving; increase of interest in } \\
\text { certain subjects }\end{array}$ \\
\hline social & $\begin{array}{l}\text { performance of teacher's requests; desire to increase } \\
\text { rating scores; desire to fulfill duties; feeling of } \\
\text { personal responsibility; development of skills to work } \\
\text { in professionally oriented group }\end{array}$ \\
\hline axiological & $\begin{array}{l}\text { self-assertion; accomplishments; acknowledgement; } \\
\text { approval }\end{array}$ \\
\hline communication & $\begin{array}{l}\text { desire to establish contact; communication in a } \\
\text { foreign language in everyday and specialized } \\
\text { situations }\end{array}$ \\
\hline professional & $\begin{array}{l}\text { desire to develop certain skills and qualities; desire to } \\
\text { realize of personal talents and wish to develop } \\
\text { individual competence }\end{array}$ \\
\hline
\end{tabular}


TABLE III. MOTIVES OF UNDERGRADUATE STUDENTS, POSTGRADUATE STUDENTS AND SPECIALISTS IN PROFESSIONALLY ORIENTED FOREIGN LANGUAGE LEARNING

\begin{tabular}{|c|l|}
\hline Motives & \multicolumn{1}{|c|}{ Motivational Contents } \\
\hline cognitive & $\begin{array}{l}\text { orientation on ways of obtaining and mastering new } \\
\text { knowledge }\end{array}$ \\
\hline social & $\begin{array}{l}\text { feeling of personal responsibility; desire to make a } \\
\text { useful contribution to society }\end{array}$ \\
\hline axiological & $\begin{array}{l}\text { self-assertion; accomplishments; acknowledgement; } \\
\text { approval; realization of individual goals and abilities }\end{array}$ \\
\hline communication & $\begin{array}{l}\text { need to acquire communication skills in a foreign } \\
\text { language in everyday, business and professional } \\
\text { situations }\end{array}$ \\
\hline $\begin{array}{c}\text { professional } \\
\text { realize to develop certain skills and qualities; desire to } \\
\text { individual competence; desire to take up a certain } \\
\text { position in a professional community }\end{array}$ \\
\hline $\begin{array}{c}\text { utilitarian and } \\
\text { practical }\end{array}$ & \begin{tabular}{l} 
material incentives \\
\hline
\end{tabular}
\end{tabular}

Data presented in the tables are of a generalized nature, since educational activity is based on various and numerous motives. It means that a set of interrelated motives functions at each age level.

Combination of motives, which creates motivation for a definite type of activity, shows clearly expressed dependence on students' personal characteristics. The conducted research aimed at revealing change in motivation in the study of a foreign language professional aspect and the experience in this field made it possible to establish that educational outcomes are determined by the following factors:

\section{Students' level of social and cultural development;}

2. Degree of professional knowledge mastering at the level of concepts and representations and a foreign language knowledge level as constituent parts of social and cultural competence;

3. Motivational basis of the process of studying professional terminology and the basic language structures in a foreign language that determine the level of students' communicative activity.

Results of motivational evolution in learning a foreign language for professional communication are presented in Figure 1. The motives shown in Fig. 1 are indicated Motive 1 (cognitive), Motive 2 (social), Motive 3 (communicative), Motive 4 (axiological), Motive 5 (professional), Motive 6 (utilitarian and practical).

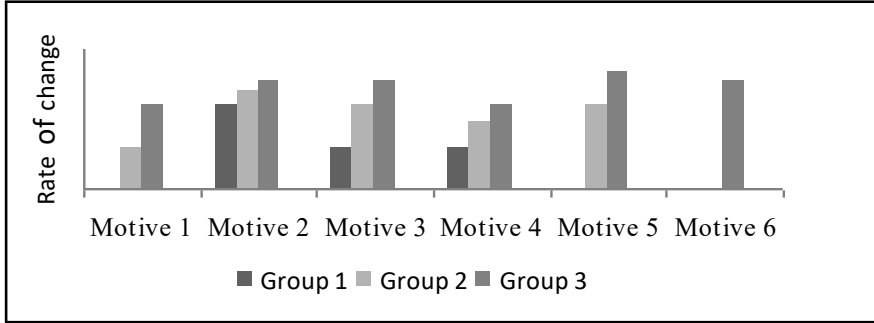

Fig. 1. Results of motivational evolution in learning a foreign language for professional communication.
It should be noted that all motives are distributed on axis $\mathrm{Y}$ according to their primary importance degree for the respondents from purely cognitive to narrowly practical. At the same time, all the motives are in close interrelation with each other and function in a complex.

\section{CONCLUSION}

Thus, the research has shown that professionally oriented foreign language learning is characterized by some modifications in various learners' motives, i.e. cognitive, social, communicative, axiological, and professional. These modifications are manifested in a form of a professional component raising value within a motivational field among experiment participants. The rate of above changes depends on social and psychological features of the experimental groups respondents. In addition, utilitarian and practical attitudes, identified in the third experimental group, are rather weakly expressed in two other groups of respondents. Actual modification of motives shows that during the period of university and post-graduate study, a person with growing economic and socio-psychological independence, as well as with well-balanced combination of intellectual and social maturity is being formed.

Development of positive motivation to diversify students' language skills creates a favorable pedagogical situation, marked by positive reactions to use new methods and teaching means to improve their learning outcomes. Taking into consideration complexity and multidimensional character of the methodological problem under research, authors presented a list of learning outcomes in teaching a foreign language to future engineers. This is to illustrate the ways teachers may follow to make both teaching and learning more competent and effective, with further development of forms and methods to solve educational tasks.

\section{REFERENCES}

[1] V. I. Belikov and L. P. Krysin, Social Linguistics, Moscow: RSHU, 2001.

[2] A. A. Verbitskiy and N. A. Bakhshaeva, "The Problem of Motives Transformation in the Contextual Education," Issues of Psychology, vol. 3, pp. 12-20, 1997.

[3] M. Guerrero, "Motivation in Second Language Learning: A Historical Overview and Its Relevance in a Public High School in Pasto, Columbia," - How - A Colombian Journal For Teachers of English, vol. 22, 1, pp. 95-106, 2015.

[4] J. Möller, "Lernmotivation," A. Renkl (Hrsg.), Lehrbuch Pädagogische Psychologie, pp. 263-298, 2008.

[5] H. Heckhausen and F. Rheinberg, "Lernmotivation im Unterricht, erneut betrachtet [Learning motivation in the classroom reconsidered]," Unterrichtswissenschaft, 8, pp. 7-47, 1980.

[6] M. Prenze, "Sechs Möglichkeiten Lernende zu demotivieren," H. Gruber and A. Renkl, (Hrsg.), Wege zum Können. Deteminanten des Kompetenzerwerbs, Bern: Huber, 1997, pp. 32-44. (URL: http://www.edushift.de/2010/08/19/sechs-moglichkeiten-lernende-zudemotivieren/)

[7] E. Ushioda, "The impact of Global English on Motivation to Learn Other Languages: Toward an ideal Multilingual self," Modern language Journal. 2017, vol. 101, 3, pp. 469-482.

[8] J. Wegge, "Lernmotivation, Informationsverarbeitung, Leistung. Zur Bedeutung von Zielen des Lernenden bei der Aufklärung motivationaler Leistungsunterschiede“. Münster: Waxmann, 1998. 
[9] J. Wegge, "Die Zielsetzungstheorie: Ein kritischer Blick auf Grundlagen und Anwendungen," O. L. Braun (Hrsg.), Ziele und Wille in der Psychologie: Grundlagen und Anwendungen, Landau: Verlag Empirische Pädagogik, 1998, pp. 3-50.

[10] A. A. Singatullova, L. R. Sakaeva, and G. K. Ismagulova, "Reading Newspaper Articles as a Motivation Tool for Students with Nonlinguitic Major," Journalof History Culture And Art Research, vol. 6, 5, pp. 179191, 2017.

[11] M. Nasihah, B. Y. Cahyono, "Language Learning Strategies, Motivation, and Writing Achievement of Indonesian EFl Students," Arab World English Journal, vol. 8, 1, pp. 250-263, 2017.

[12] O. V. Sumtsova, Yu. P. Azhel, A. S. Buyankina, "Webquest-Based Role Play as a Way of Raising Students' Motivation to Studying Foreign Languages," International Journal of Emerging Technologies In Learning, vol. 11, 3, p. 63-66, 2016.

[13] JLR Robles, "The Effect of the Flipped Classroom Method on PreIntermediate Level Students' Motivation to Learn English as a Foreign Language," Atoz-Novas Praticas Em Informacao E Conhecimento, vol. 5, 2, pp. 104-114, 2016.

[14] A. N. Leontiyev, Activities. Consciousness. Personality, Moscow: Science, 1975.

[15] N. A. Frolova, I. V. Aleshchanova, "To the Question of Motivation Increase in Foreign Language Professionally Oriented Education," Topical Questions of Professional Education, 1 (2), pp. 73-77, 2016.

[16] I. V. Aleshchanova, N. A. Frolova "Didactic Methods of Educational and Cognitive Development," The International Journal of Applied and Fundamental Research, 12, pp. 691-695, 2016.

[17] V. I. Kovalev, Motives of Behavior and Activities, Moscow: Pedagogy, 1988.

[18] A. G. Maslow, Motivation and Personality, St. Petersburg: Eurasia, 1999.

[19] O. A. Shlyapnikova, Motivation of Educational Activity: Training Manual, Yaroslavl: YarSU, 2014.

[20] E. Deci and R. Ryan. Handbook of Self-Determination Research, Rochester, NY: University of Rochester Press, 2002.

[21] O. K. Klopova, "Methods of Students' Motivational Encouragement in Skills Development," Humanitarian: Topical Problems of Science and Education. Saransk: MSU. 2009, 8, pp. 208-212.
[22] G. V. Dub and I. E. Khrusyn, "Reasons for Students' Demotivation in Foreign Language Classes at the University," Theory and Practice of Social Development. Stavropol: SSAU, 2012, 12, pp. 170-172.

[23] I. M. Podushkina, "Motivational and Value Conditions of the University Professor's Readiness Provision for Innovative Challenges," Scholarly Notes. Electronic Journal of KSU. Kursk. 2012, 4-1 (24), pp. 114-121.

[24] L. M. Asmolova, "Motivational management as a factor of educational organizations success in conditions of FSESs implementation", Domestic and foreign pedagogy, 4 (31), pp. 33-48, 2016.

[25] U. Schiefele. "The role of interest in motivation and learning," J. M. Collis \& S. Messick (Eds.), Intelligence and personality: Bridging the gap in theory and measurement, Mahwah, NJ: Erlbaum, 2001, pp. 163194.

[26] I. V. Aleshchanova, N. A. Frolova, E. V. Morozova, and M. R. Zheltukhina, "Psychological and Acmeological Aspect of Educational Cognitive Competence Development," Proceedings of the 7th International Scientific and Practical Conference Current Issues of Linguistics and Didactics: The Interdisciplinary Approach in Humanities (CILDIAH 2017). Advances in Social Science, Education and Humanities Research (ASSEHR), 97, pp. 19-24, 2017.

[27] E. V. Bobyreva, O. A. Dmitrieva, M. R. Zheltukhina, and M. V. Busygina, "Principle "Understanding" from Perspective of Linguistic Investigations," Proceedings of the 7th International Scientific and Practical Conference Current Issues of Linguistics and Didactics: The Interdisciplinary Approach in Humanities (CILDIAH 2017). Advances in Social Science, Education and Humanities Research (ASSEHR), 97, pp. 52-56, 2017.

[28] D. Yu. Gulinov, M. R. Zheltukhina, L. A. Shestak, G. G. Slyshkin, V. V. Katermina, and L. D Chervyakova. "Modern Language Policy: Specifics of Formation and Development of the French Vertical", Modern Journal of Language Teaching Methods, vol. 8, 2, pp. 159-173, February 2018.

[29] G. N. Ostrikova, M. R. Zheltukhina, I. A. Zyubina and I. G. Sidorova. "Learning Via Visualization at the Present Stage of Teaching a Foreign Language," Astra Salvensis, 1, p. 601-607, VI 2018. 